\title{
Utilization of Big Data Analysis as a Supporting System of Therapy Treatment for URI (Upper Respiratory Tract Infection) Patients
}

\author{
Novita Nuraini* \\ Department of Health \\ Politeknik Negeri Jember \\ Jember, Indonesia \\ novita_nuraini@polije.ac.id
}

\author{
Sustin Farlinda \\ Department of Health \\ Politeknik Negeri Jember \\ Jember, Indonesia \\ sustin@polije.ac.id \\ Fitriana Putri \\ Faculty of Health Science \\ Muhammadiyah University of Jember \\ Jember, Indonesia \\ fitrianaputri@unmuhjember.ac.id
}

\author{
Rossalina Adi Wijayanti \\ Department of Health \\ Politeknik Negeri Jember \\ Jember, Indonesia \\ rossa@ polije.ac.id
}

\begin{abstract}
The provision of medical record files at Pesantren Public Health Center 2 Kediri exceed the maximum time limit of 10 minutes. This condition causes a longer patient waiting time, medical service process will be hampered, and reduce the quality of health service facilities. The purpose of this study was to analyze the factors that cause delays in providing medical record documents at Pesantren II Kediri Health Center and prioritizing the causes of problems with the Multiple Criteria Utility Assessment method. This research was qualitative, data was collected through observation and interviews with 4 informants. The results showed that there were no awards and punishment for officers, malfunction tracer, officers education not a medical record, officers never conduct training or workshops, officers perception that Standard Operating Procedure cannot be applied. Based on Multiple Criteria Utility Assessment method, the highest cause of delay in provision of medical record files was the malfunctioning of tracer. Conclusion: The results suggest redesigning tracers and socializing the use of tracers, training for medical records officers, and routine evaluation for provisioning medical record file.
\end{abstract}

\section{Keywords-medical record, tardiness, public health center}

\section{INTRODUCTION}

Quality or quality is a measure of the merits of a product or service that is valued by customers from the similarity to established standards. There are five main dimensions of quality, namely tangibles, reliability, responsiveness, assurance, and empathy, commonly known as service quality theory and can be used as indicators to measure the quality or quality of health services in Puskesmas. The quality of health services is a health service that can provide whatever patients need when receiving services so that it will cause satisfaction for these patients [9]. Upper Respiratory Tract Infection (URI) becomes a major cause of morbidity and mortality of infectious diseases in the world. Nearly four million people die from ARI each year, $98 \%$ are due to lower respiratory tract infections [9].
This infection ranked the first position in the top 15 of the highest diseases in 2015 in Jember Regency [2]. The cure rate for URI patients at Puskesmas Ambulu is still low [4]. This condition shows that the service effectiveness of ARI cases is still lacking. Menawhile, Dr. M Suherman Pratama Clinic has a fast development. The number of patient visits has increased each year in this clinic.

In 2019 , there were 250 outpatient visits per day, $75 \%$ of the visits were URI patients. This condition indicates high number of ARI visits to the clinic. However, the results of the patient survey found complaints in the service waiting time. Previous research showed that the average waiting time at the Pratama Clinic dr. M. Suherman was 93.8 minutes. The length of waiting time is not in accordance with the standard set by the Ministry of Health, at least $\leq 60$ minutes [7]

The preliminary survey (March, 2020) revealed that the long waiting time for the services was partly due to the process of drugs prescription by doctors. The various drugs compositions for each patient make the administration of this input in the clinic became longer. There were also an increase in the number of URI patients who arrive for medical control.

The use of technology is designed to help process relevant data, information and therapy knowledge to support effective URI care, prevention and control. Big Data Analytics (BDA) can help organizations to have a better understanding of the information contained in data and to identify data that is important for management's decision making [6]. In BDA, data mining is one of the important processes in finding knowledge because it is related to searching data to find patterns from the whole data. It is used to analyze data describing data classes or to predict future data. [11].

Research that uses classification in predicting data has been widely applied to diagnose a disease, e.g. breast cancer [12], stroke [13], applied to diagnose pneumonia in toddlers [14]. In this study, using the C4.5 algorithm in providing predictive results by selecting or separating the characteristics 
in each information available. The $\mathrm{C} 4.5$ algorithm is a widely used decision tree classification algorithm because it has the main advantages of being able to produce a decision tree that is easy to interpret, it has an acceptable level of accuracy, efficient in handling discrete and numeric type attributes [15] and also useful for exploring data, it can find a hidden relationship between a number of candidate input variables with a target variable [16]

The use of BDA is expected to produce a process that is full of information and knowledge that can help the of control URI effectively so that the cure rate for URI patients can increase as evidenced by the decrease in the number of control visits and the incidence of allergies by utilizing the patient's drug allergy history data, and reducing the length of waiting time for the drug input process by the doctor.

\section{RESEARCH METHOD}

Several stages that will be done in this design: (1) Data Collection (2) Big Data Analysis Process (3) Data Visualization (4) Designing the Mode

\section{A. Data Collection}

The data used are from the outpatients' data with a diagnosis of J00 or URI at dr. M. Suherman Clinic in 2017 2019. Collecting data through the reporting menu in the existing information system, obtained a total of 34973 events J00.

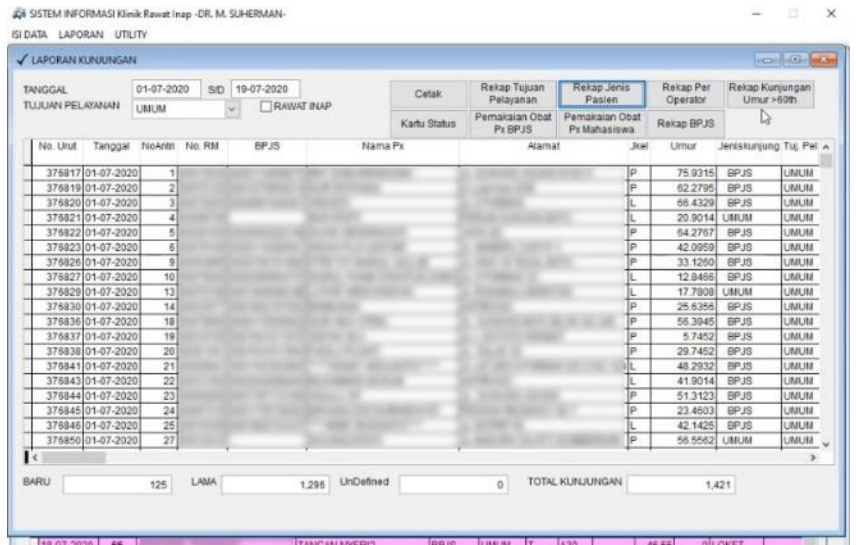

Fig. 1. The Page of Pasients' Visit Report

\section{B. Big Data Analysis Process}

Big data is a mixture of structured and unstructured data sets. The data typically consists of data in an unstructured format requiring large storage space and effort to manage. MapReduce is an analytical function which is capable to analyze larger distributed data sets, but traditional methods are not suitable for large data in which heterogeneity, speed and volume act as barriers to the analysis process. Big data is characterized by MySQL that has no schema, no data description language, but supports transaction processing. Parallel and distributed processing becomes standard approach implemented. The traditional methods that involved data storage, summary and online analytical processing are completely different as in big data. The next step is to use an advanced analytical approach, which includes a variety of methods and tools covering predictive analysis, data mining, statistical analysis, complex SQL, data visualization, artificial intelligence, and natural language processing. The characteristics of big data influence the need for specialized processing systems.

\section{Data Visualization}

Data visualization is an important part of big data analysis, especially when it comes to descriptive analysis. By the use of data visualization, we can read and analyze data in a visual form and then take values or insights from the data easily. To visualize data, we can create scripts in python language and help libraries such as Matplotlib, Bokeh, Seaborn, Ggplot, and so on. However, this study applies data visualization software. One of the software to simulate data is table.

\section{Recommendations of Therapy Treatment for URI Patients}

An appropriate therapy formulation will be generated by collecting historical patient data as a recommendation for therapy of URI patients who come to the clinic. The therapy formulation is based on:

1. Patient identity data includes age, gender

2. Physical examination data by nurses and doctors, including weight, temperature, and health complaints; Coughs, Colds, and Inflammation

3. Medical history data

4. Health facility drug formulary data

\section{RESULTS}

\section{A. Process and Data Transformation}

Processing only requires four attributes, such as: Category Age, weight, date of the treatment, complaints, and Disease Code as the objective attributes of this study. So that the data transformation process need to be processed, after the data transformation is carried out, the processing will be carried out using the $\mathrm{C} 4.5$ algorithm. Some transformations are carried out by creating groups of data on several attributes that have a sufficiently large range of data; including age, weight and fever:

\begin{tabular}{ll}
\hline Kategori & \multicolumn{1}{c}{ Usia } \\
\hline Anak & $<=12$ \\
\hline Dewasa & $>12$ \\
\hline
\end{tabular}

\begin{tabular}{ll}
\hline Kategori & $\begin{array}{c}\text { Suhu } \\
\text { Badan }\end{array}$ \\
\hline Demam & $>37.3$ \\
\hline Tidak & $<=37.3$ \\
\hline
\end{tabular}

\begin{tabular}{cc}
\hline Kategori & $\begin{array}{c}\text { Berat } \\
\text { Badan }\end{array}$ \\
\hline 1 & $<12 \mathrm{Kg}$ \\
\hline 2 & $12-25 \mathrm{Kg}$ \\
\hline 3 & $26-50 \mathrm{Kg}$ \\
\hline 4 & $>50 \mathrm{Kg}$ \\
\hline
\end{tabular}

Data samples that have been transformed can be seen in table 1 .

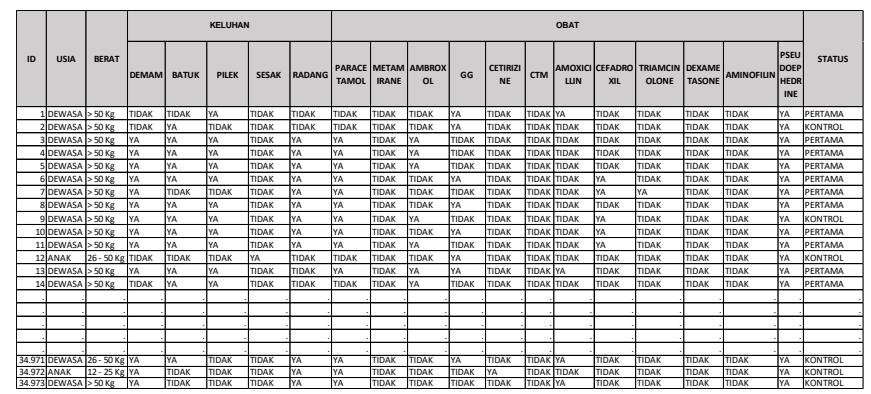




\section{B. Total Entropy Value and Gain (Root)}

Data processing begins by finding the total entropy of all attributes and then determining the highest gain. To get the gain value in the formation of a decision tree, it is necessary to first calculate the information value in bits from a collection of objects. The value of Entropy $(\mathrm{X})$ indicates that $\mathrm{X}$ is a random attribute. The entropy value reaches a minimum value of 0 , when all other $\mathrm{pj}=0$ or are in the same class. In the C4.5 tree construction, each node of the tree is filled with attributes with the highest gain ratio value.

The process of finding total entropy and gain is done by grouping the data correctly, then calculating the data and using the entropy and gain search formulas for each data attribute.

\begin{tabular}{|c|c|c|c|}
\hline \multirow{2}{*}{ Atribute } & \multirow{2}{*}{$\begin{array}{c}\text { Jumlah } \\
\text { Kasus }\end{array}$} & \multicolumn{2}{|l|}{ Status Periksa } \\
\hline & & Pertama & Kontrol \\
\hline \multicolumn{4}{|l|}{ Usia } \\
\hline Anak & 13077 & 9792 & 3285 \\
\hline Dewasa & 21896 & 16467 & 5429 \\
\hline \multicolumn{4}{|l|}{ Berat Badan } \\
\hline$<12 \mathrm{Kg}$ & 937 & 720 & 217 \\
\hline $12-25 \mathrm{Kg}$ & 6980 & 5221 & 1759 \\
\hline $26-50 \mathrm{Kg}$ & 6113 & 4583 & 1530 \\
\hline$>50 \mathrm{Kg}$ & 20943 & 15735 & 5208 \\
\hline \multicolumn{4}{|l|}{ KELUHAN } \\
\hline $\begin{array}{l}\text { DEMAM, BATUK, PILEK, SESAK, } \\
\text { RADANG }\end{array}$ & 106 & 80 & 26 \\
\hline DEMAM, BATUK, PILEK, SESAK & 287 & 214 & 73 \\
\hline DEMAM, BATUK, PILEK, RADANG & 6313 & 4746 & 1567 \\
\hline DEMAM, BATUK, SESAK, RADANG & 87 & 58 & 29 \\
\hline DEMAM, PILEK, SESAK, RADANG & 13 & 12 & 1 \\
\hline BATUK, PILEK, SESAK, RADANG & 19 & 16 & 3 \\
\hline DEMAM, BATUK, PILEK & 10490 & 7821 & 2669 \\
\hline DEMAM, BATUK, SESAK & 133 & 91 & 42 \\
\hline DEMAM, BATUK, RADANG & 1980 & 1452 & 528 \\
\hline DEMAM, PILEK, SESAK & 20 & 16 & 4 \\
\hline DEMAM, PILEK, RADANG & 622 & 471 & 151 \\
\hline DEMAM, SESAK, RADANG & 40 & 31 & 9 \\
\hline BATUK, PILEK, SESAK & 124 & 94 & 30 \\
\hline BATUK, PILEK, RADANG & 562 & 426 & 136 \\
\hline BATUK, SESAK, RADANG & 14 & 10 & 4 \\
\hline PILEK, SESAK, RADANG & 3 & 2 & 1 \\
\hline DEMAM, SESAK & 53 & 41 & 12 \\
\hline DEMAM, RADANG & 4047 & 3062 & 985 \\
\hline BATUK, PILEK & 3590 & 2718 & 872 \\
\hline BATUK, SESAK & 3590 & 2718 & 872 \\
\hline BATUK, RADANG & 309 & 237 & 72 \\
\hline PILEK, SESAK & 12 & 9 & 3 \\
\hline PILEK, RADANG & 82 & 63 & 19 \\
\hline SESAK, RADANG & 14 & 10 & 4 \\
\hline DEMAM, BATUK & 1978 & 1485 & 493 \\
\hline DEMAM, PILEK & 1570 & 1207 & 363 \\
\hline BATUK & 1146 & 848 & 298 \\
\hline PILEK & 547 & 412 & 135 \\
\hline SESAK & 47 & 37 & 10 \\
\hline
\end{tabular}

Entropy is a parameter to measure the level of diversity (heterogeneity) of a data set. The greater the value of the entropy, the greater the diversity of a data set. The formula for calculating entropy is as follows:

$$
\operatorname{Entropy}(S)=-\sum_{i=1}^{m} p_{i} \log _{2}\left(p_{i}\right)
$$

dimana:

$$
\begin{array}{ll}
m & =\text { jumlah kelas klasifikasi } \\
p_{i} & =\text { jumlah proporsi sampel (peluang) untuk kelas } \mathrm{i}
\end{array}
$$

Meanwhile, the formula for entropy in each variable is:

$$
\operatorname{Entropy}_{A}(S)=\sum_{v} \frac{\left|S_{v}\right|}{|S|} \operatorname{Entropy}\left(S_{v}\right)
$$

\begin{tabular}{|c|c|c|c|c|}
\hline \multirow{2}{*}{ Atribute } & \multirow{2}{*}{$\begin{array}{c}\text { Jumlah } \\
\text { Kasus }\end{array}$} & \multicolumn{2}{|c|}{ Status Periksa } & \multirow{2}{*}{ Entrophy } \\
\hline & & Pertama & Kontrol & \\
\hline $\begin{array}{l}\text { DEMAM, BATUK, PILEK, SESAK, } \\
\text { RADANG }\end{array}$ & 106 & 80 & 26 & 0,803 \\
\hline DEMAM, BATUK, PILEK, SESAK & 287 & 214 & 73 & 0,817 \\
\hline DEMAM, BATUK, PILEK, RADANG & 6313 & 4746 & 1567 & 0,808 \\
\hline DEMAM, BATUK, SESAK, RADANG & 87 & 58 & 29 & 0,918 \\
\hline DEMAM, PILEK, SESAK, RADANG & 13 & 12 & 1 & 0,385 \\
\hline BATUK, PILEK, SESAK, RADANG & 19 & 16 & 3 & 0,629 \\
\hline DEMAM, BATUK, PILEK & 10490 & 7821 & 2669 & 0,818 \\
\hline DEMAM, BATUK, SESAK & 133 & 91 & 42 & 0,9 \\
\hline DEMAM, BATUK, RADANG & 1980 & 1452 & 528 & 0,837 \\
\hline DEMAM, PILEK, SESAK & 20 & 16 & 4 & 0,721 \\
\hline DEMAM, PILEK, RADANG & 622 & 471 & 151 & 0,8 \\
\hline DEMAM, SESAK, RADANG & 40 & 31 & 9 & 0,769 \\
\hline BATUK, PILEK, SESAK & 124 & 94 & 30 & 0,798 \\
\hline BATUK, PILEK, RADANG & 562 & 426 & 136 & 0,798 \\
\hline BATUK, SESAK, RADANG & 14 & 10 & 4 & 0,863 \\
\hline PILEK, SESAK, RADANG & 3 & 2 & 1 & 0,918 \\
\hline DEMAM, SESAK & 53 & 41 & 12 & 0,772 \\
\hline DEMAM, RADANG & 4047 & 3062 & 985 & 0,8 \\
\hline BATUK, PILEK & 3590 & 2718 & 872 & 0,8 \\
\hline BATUK, SESAK & 142 & 111 & 31 & 0,757 \\
\hline BATUK, RADANG & 309 & 237 & 72 & 0,783 \\
\hline PILEK, SESAK & 12 & 9 & 3 & 0,811 \\
\hline PILEK, RADANG & 82 & 63 & 19 & 0,781 \\
\hline SESAK, RADANG & 14 & 10 & 4 & 0,724 \\
\hline DEMAM, BATUK & 1978 & 1485 & 493 & 0,809 \\
\hline DEMAM, PILEK & 1570 & 1207 & 363 & 0,779 \\
\hline BATUK & 1146 & 848 & 298 & 0,826 \\
\hline PILEK & 547 & 412 & 135 & 0,806 \\
\hline SESAK & 47 & 37 & 10 & 0,746 \\
\hline RADANG & 623 & 479 & 144 & 0,779 \\
\hline
\end{tabular}

dimana:

$$
\begin{array}{ll}
A & =\text { variabel } \\
v & =\text { nilai yang mungkin untuk variabel } \mathrm{A} \\
\left|S_{v}\right| & =\text { jumlah sampel untuk nilai } \mathrm{v} \\
|S| & =\text { jumlah sampel untuk seluruh sampel data }
\end{array}
$$

Entropy $\left(S_{v}\right)=$ Entropy untuk sampel yang memiliki nilai $\mathrm{v}$

\section{CONCLUSION AND RECOMMENDATION}

\section{A. Conclusion}

As the effort to assist doctors in providing therapy for URI patients, by utilizing the output of Big Data Analysis as an alternative solution to these following problems:

- The application of big data analysis using the C.45 algorithm can be used to help researchers analyze therapy data for URI patients (J00) with several attributes that affect each patient's visit record in the future.

- This system is designed to help doctors determine drug recommendations in therapy treatment for URI patients.

\section{B. Recommendation}

The next stage is how this system can be integrated with the existing information system in the Clinic of dr. M. Suherman. 


\section{ACKNOWLEDGMENT}

This paper is written to fulfil one of the requirements of research implementation project funded by BOPTN. We express our deepest gratitude to the Ministry of Education and Culture of the Republic of Indonesia for this financial support, to dr. H. Suherman Clinic for the data obtained, and Politeknik Negeri Jember for the administrative supports.

\section{REFERENCES}

[1] Big Data 2013. Analytics Advanced Analytics in Oracle Database, An Oracle White

[2] Farlinda S, Hikmah F dan Rozi F 2018, Pembuatan Webgis Penyakit Infeksi Saluran Pernafasan Akut (ISPA) di Kabupaten Jember Tahun 2013-2015 (The Manufacture of Webgis For Acute Respiratory Tract Infections (Ari) In Jember Regency In 2013-2015), Jurnal Manajemen Informasi Kesehatan Indonesia. Vol. 6 No.2 Oktober 2018 ISSN: 2337 6007 (online); 2337-585X (Printed)

[3] Kusumasari D dan Rafizan O 2017, Studi Implementasi Sistem Big Data untuk Mendukung Kebijakan Komunikasi dan Informatika, Jurnal Masyarakat Telematika dan Informasi, Volume: 8 No. 2 (Oktober - Desember 2017) Hal.: 81-96. diakses 29 Maret 2020, < https://media.neliti.com/media/publications/233736-studiimplementasi-sistem-big-data-untuk-857db2bd.pdf $>$.

[4] Maghfirah, M.D., 2015. Analisis Klasifikasi Penyakit Infeksi Saluran Pernafasan Akut Terhadap Tingkat Kesembuhan Pasien Berdasarkan Berkas Rekam Medis Rawat Jalan Di Puskesmas Ambulu Tahun 2014. Skripsi. Politeknik Negeri Jember.

[5] Mayasari E 2015, Analisis Faktor Risiko Kejadian ISPA Ditinjau dari Status Rumah di Wilayah Kerja Puskesmas Kota Wilayah Utara Kota Kediri, Jurnal IKESMA. Volume 11 Nomor 1 September 2015. diakses 29 Maret 2020

[6] Min Chen, Shiwen Mao, Yunhao Liu, 2014. "Big Data: A Survey", Mobile Netw Appl Springer Science+ Business Media New York, 19: 171-209.

[7] Nuraini N dan Wijayanti RA 2018, Optimalisasi Waktu Tunggu Rawat Jalan dengan Metode LEAN Healthcare di Klinik Pratama, Jurnal
Manajemen Informasi Kesehatan Indonesia. Vol. 6 No.1 Maret 2018 ISSN: 2337-6007 (online); 2337-585X (Printed)

[8] Putra Y dan Sekar Sri Wulandari SS 2019, Faktor Penyebab Kejadian ISPA, JURNAL KESEHATAN : STIKES PRIMA NUSANTARA BUKITTINGGI - VOL. 10 NO. 01 (2019), diakses 29 Maret 2020

[9] WHO 2007a, Infeksi saluran pernapasan akut (ISPA) yang cenderung menjadi epidemi dan pandemic, diakses 29 Maret 2020,

[10] WHO 2007b, Pencegahan dan pengendalian infeksi saluran pernapasan akut (ISPA) yang cenderung menjadi epidemi dan pandemi di fasilitas pelayanan kesehatan, diakses 29 Maret 2020,

[11] Dharm Singh, Naveen Choudhary and Jully Samota. (2013). Analysis of Data Mining Classification with Decision Tree Technique. Global Journal of Computer Science \& Data Engineering, Vol.13 Issue 13

[12] Ronak Sumbaly, N. Ishnusri, S.Jeyalatha. (2014). Diagnosis of Breast Cancer using Decision Tree Data Minin Technique. International Journal of Computer Application, Vol.98 No.10,Hal : 16-24.

[13] Sigit Abdillah.(2011). Penerapan Algoritma Decision Tree C4.5 Untuk Diganosa Penyakit Stroke dengan klasifikasi Data Mining Pada Rumah Sakit Santa Maria Pemalang.

[14] Akbar Mujahidin dan Denny Pribadi 2017, Penerapan Algoritma C4.5 Untuk Diagnosa Penyakit Pneumonia Pada Anak Balita Berbasis Mobile, Jurnal SWABUMI. Vol. 5 No.2 September 2017 ISSN: 2355990X Volume 4 no 1, April 2020.

[15] Kamagi, D. H., \& Hansun, S. (2014). Implementasi Data Mining dengan Algoritma C4. 5 untuk Memprediksi Tingkat Kelulusan Mahasiswa. ULTIMATICS, 6(1).

[16] Kusrini, E. T. L. (2009). Algoritma Data Mining. Yogyakarta: Andi Offset.

[17] Bramer, Max (2007) Principles of Data Mining, Springer Science

[18] LI Rui, WEI Xian-mei, YU Xue-wei, IEEE 2009. The Improvement of C4.5 Algorithm and Case Study. IEEE Second International Symposium on Computational Intelligence and Design.

[19] Umi Hanik, 2011, Fuzzy Decision Tree dengan Algoritma C.45 pada data jantung Rumah Sakit Jantung Harapan Kita, STMIK Triguna Dharma, Jakarta 